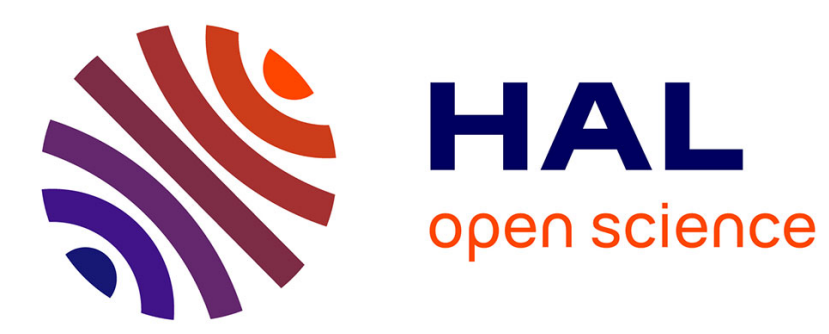

\title{
Topotactic transformations of goethite and lepidocrocite into hematite and maghemite
}

Yannick Cudennec, André Lecerf

\section{To cite this version:}

Yannick Cudennec, André Lecerf. Topotactic transformations of goethite and lepidocrocite into hematite and maghemite. Solid State Sciences, 2005, 7 (5), pp.520-529. 10.1016/j.solidstatesciences.2005.02.002 . hal-02537313

\section{HAL Id: hal-02537313 \\ https://hal.science/hal-02537313}

Submitted on 8 Apr 2020

HAL is a multi-disciplinary open access archive for the deposit and dissemination of scientific research documents, whether they are published or not. The documents may come from teaching and research institutions in France or abroad, or from public or private research centers.
L'archive ouverte pluridisciplinaire HAL, est destinée au dépôt et à la diffusion de documents scientifiques de niveau recherche, publiés ou non, émanant des établissements d'enseignement et de recherche français ou étrangers, des laboratoires publics ou privés. 


\title{
Solid State Sciences
}

\section{Volume 7, Issue 5, May 2005, Pages 520-529}

\section{https://doi.org/10.1016/j.solidstatesciences.2005.02.002}

\section{Yannick Cudennec*, André Lecerf}

Groupe de Recherche en Chimie et Métallurgie, Institut National des Sciences Appliquées de Rennes, 20 avenue des buttes de Coësmes, 35043 Rennes cedex, France.

\begin{abstract}
Goethite $(\alpha-\mathrm{FeOOH})$, lepidocrocite $(\gamma-\mathrm{FeOOH})$, hematite $\left(\alpha-\mathrm{Fe}_{2} \mathrm{O}_{3}\right)$ and maghemite $\left(\gamma-\mathrm{Fe}_{2} \mathrm{O}_{3}\right)$ constitute the main natural occurrences with magnetite $\left(\mathrm{Fe}_{3} \mathrm{O}_{4}\right)$, for ferric oxides and oxyhydroxides.

By thermal dehydrations goethite and lepidocrocite respectively give rise to hematite and maghemite by topotactic transformations. In fact, this kind of transformation permits alone to explain why hematite, the most stable oxide in a thermodynamical point of view, is not obtained directly by dehydration of lepidocrocite. Topotactic transformations can only exist between solids displaying structural relationships. In these conditions, atom displacements are reduced so that dehydration processes are performed at a relatively low temperature and then clear vectorial relations can be established between crystal parameters of the two structures. Therefore, we can consider that trivalent iron oxyhydroxides and oxides, belong to two different structural types: goethite/hematite type and lepidocrocite/maghemite type and conclude that, in this case, kinetic phenomena are more important than laws of thermodynamic for explaining the experimental results found.
\end{abstract}

Key words: iron oxides, iron oxyhydroxides, topotactic transformations, thermal dehydrations, thermodynamic studies, crystallographic studies. 
* Author to whom correspondence must be send

\section{INTRODUCTION}

Goethite $(\alpha-\mathrm{FeOOH})$, lepidocrocite $(\gamma-\mathrm{FeOOH})$, hematite $\left(\alpha-\mathrm{Fe}_{2} \mathrm{O}_{3}\right)$ and maghemite $\left(\gamma-\mathrm{Fe}_{2} \mathrm{O}_{3}\right)$ constitute the main natural occurrences for ferric oxides and oxyhydroxides. Their use as inorganic pigments, raw materials for iron and steel industries and precursor materials for the production of permanent magnets, is of great importance because of their non-toxicity, their chemical stability and their low production costs.

Cornell and Schwertmann [ 1 ] have reviewed the whole literature about these compounds in a book published in 1996. Since this work, many studies have been carried out, particularly on topotactic transformations between these different solid phases [2-9]. If the main chemical steps which are of importance during the production of hematite and maghemite are correctly established, the mechanism of the solid state transformation is not yet fully understood.

In addition, all the different aspects of the question and particularly, thermodynamic studies and relationship between crystal structures, revisited thanks to new and more efficient tools which appeared during the last ten years, allows the formulation of hypotheses of reacting mechanisms which explain better, experimental results.

In this way, in a recent publication [10] we have studied the formation processes of iron oxyhydroxides from divalent iron solutions and particularly the oxidation of Green Rust into lepidocrocite by a topotactic transformation which preserves the lamellar feature of the brucite type precursor. Therefore, the aim of this publication is to continue that study by thermal dehydrations of goethite and lepidocrocite which respectively give rise to hematite and maghemite by topotactic transformations. In fact, this kind of transformation alone permits to explain why hematite, the most stable oxide, is not obtained directly by dehydration of lepidocrocite. 


\section{Thermodynamic studies and stability}

In application of the second law of thermodynamic, the free enthalpy $\mathrm{G}_{\mathrm{T}, \mathrm{P}}$, can only decrease till a minimum that corresponds to equilibrium, for chemical reactions carried out at constant temperature and pressure [11]. It means that, before equilibrium, the derivative of $\mathrm{G}_{T, P}$ with respect to $\xi$, the extent of reaction ( measure of the progress of the reaction) is negative: $(\mathrm{dG} / \mathrm{d} \xi)_{\mathrm{T}, \mathrm{P}}<0$. When the system is at equilibrium, value of the derivative is zero: $(\mathrm{dG} / \mathrm{d} \xi)_{\mathrm{T}, \mathrm{P}}=$ 0 . Therefore, one can consider the derivative of $\mathrm{G}_{\mathrm{T}, \mathrm{P}}$ as an evolution criterion for reacting systems.

At low pressures, as thermodynamic functions of solids and liquids are practically not depending of pressure, then the derivative is approximately equal to:

$$
(\mathrm{dG} / \mathrm{d} \xi)_{\mathrm{T}, \mathrm{P}}=\Delta_{\mathrm{r}} \mathrm{G}_{\mathrm{T}, \mathrm{P}} \approx \Delta_{\mathrm{r}} \mathrm{G}_{\mathrm{T}}^{\circ}+\mathrm{RT} \ln \mathrm{Q}_{\mathrm{R}}[11]
$$

$\Delta_{\mathrm{r}} \mathrm{G}_{\mathrm{T}, \mathrm{P}}$ is the reaction Gibbs function. It differs from zero at compositions out of equilibrium for $\xi \neq \xi_{\text {eq }}$ and becomes equal to zero at equilibrium.

$\Delta_{\mathrm{r}} \mathrm{G}_{\mathrm{T}}^{\circ}$ is the standard reaction Gibbs function ( this is a constant at $\mathrm{T}$ which can be calculated thanks to thermodynamic tables ).

$\mathrm{Q}_{\mathrm{R}}$ is the reaction quotient which is depending of partial pressures in presence of a mixture of gases. It is related to the starting conditions apart from equilibrium and is a function of $\xi$. At

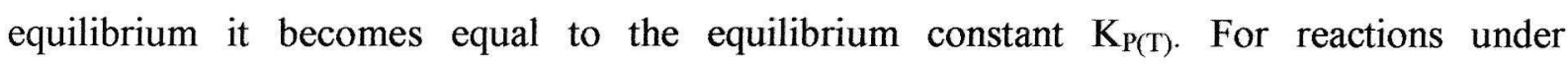
consideration, $\mathrm{Q}_{\mathrm{R}}=\left(\mathrm{P}_{(\mathrm{H} 2 \mathrm{O})} / \mathrm{P}^{\circ}\right)^{1 / 2}$ (see reactions below).

On the other hand, in the case of reactions between solid phases only, the derivative of $\mathrm{G}_{\mathrm{T}, \mathrm{P}}$ is nearly equal to the standard reaction function : $\left(\mathrm{dG} / \mathrm{d} \xi_{\mathrm{T}, \mathrm{P}}=\Delta_{\mathrm{r}} \mathrm{G}_{\mathrm{T}, \mathrm{P}} \approx \Delta_{\mathrm{r}} \mathrm{G}_{\mathrm{T}}^{\circ}\right.$.

In a recent publication Majzlan et al.[6] studied the relative stability of goethite, lepidocrocite and maghemite and proposed experimental data for enthalpies, free enthalpies of formation 
and entropies at $298.15 \mathrm{~K}$. Thanks to these new data we have calculated the evolution criterion for the following reactions at 298.15 and $373.15 \mathrm{~K}$ :

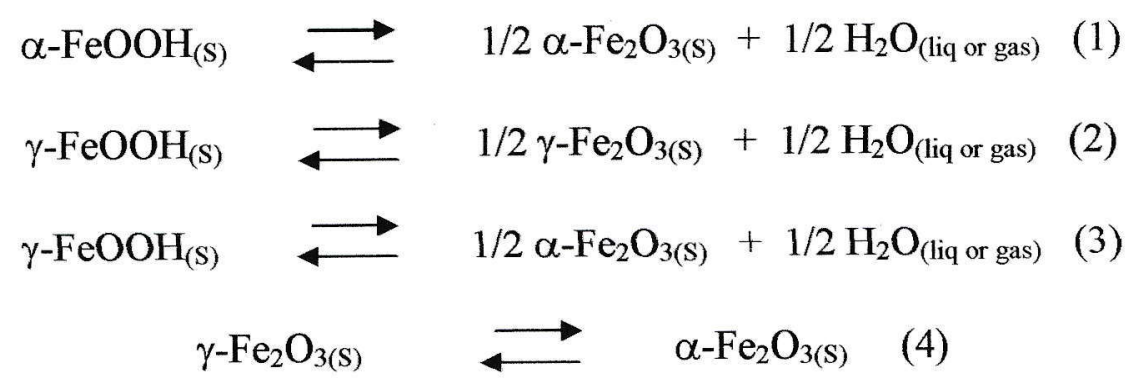

Experimental values of thermodynamic functions used for calculations are reported in table1 and results obtained for reaction functions with $\mathrm{H}_{2} \mathrm{O}$ as liquid or gas, in table 2 .

For all the reactions at $298 \mathrm{~K}, \Delta_{\mathrm{r}} \mathrm{G}_{298}^{\circ}$ is negative( see table 2) and for reactions (1-3), carried out in open air with $\mathrm{H}_{2} \mathrm{O}$ as gas, $\mathrm{Q}_{\mathrm{R}}=\left(\mathrm{P}\left({ }_{\mathrm{H} 2 \mathrm{O}}\right) / \mathrm{P}^{\circ}\right)^{1 / 2}<1$ so that $\mathrm{RT} \ln \mathrm{Q}_{\mathrm{R}}<0$. Therefore derivative of $G_{T, P}$ is always negative. It means that, from a thermodynamical point of view, hematite is the only stable phase. At higher temperatures that is still more true because reaction entropies $\Delta_{\mathrm{r}} \mathrm{S}_{298}^{\circ}$ are always positive (see table 2) and the evolution of $\Delta_{\mathrm{r}} \mathrm{G}_{\mathrm{T}}^{\circ}$ with temperature is done with a good approximation, by the approximate relation: $\Delta_{\mathrm{r}} \mathrm{G}_{\mathrm{T}}^{\circ} \approx \Delta_{\mathrm{r}} \mathrm{H}_{298}^{\circ}$ - T $\Delta_{\mathrm{r}} \mathrm{S}_{298}^{\circ}$. In fact, $\Delta_{\mathrm{r}} \mathrm{H}_{\mathrm{T}}^{\circ}$ and $\Delta_{\mathrm{r}} \mathrm{S}_{\mathrm{T}}^{\circ}$ can be considered as constant and equal to respectively $\Delta_{\mathrm{r}} \mathrm{H}_{298}^{\circ}$ and $\Delta_{\mathrm{r}} \mathrm{S}_{298}^{\circ}$, in the range of temperature where the reactions are performed.

\section{Experimental results for thermal dehydration of iron oxyhydroxides}

Several studies about decomposition of goethite to hematite by heating are reported in the previous work of Cornell and Schwertmann [1]. Goethite proceeds directly to hematite without any intermediate phase. The temperature and the activation energy of the transformation, strongly depend on crystallinity and particle size of the sample: $\mathrm{T}=533$ to $593 \mathrm{~K}$ and $\mathrm{E}_{\mathrm{ac} .}=87.9$ to $247 \mathrm{~kJ} \cdot \mathrm{mol}^{-1}$. In a recent publication Walter et al.[8] proposed a 
temperature of decomposition around $543 \mathrm{~K}$ ( maximum of endothermic DTA peak) for a small-size particle goethite sample.

Unlike goethite, lepidocrocite transforms upon heating first to maghemite and then, at higher temperatures, to hematite. The first transformation temperature is between $473-553 \mathrm{~K}$ in air and the activation energy between 104-134 $\mathrm{kJ} \mathrm{mol}^{-1}$. These values are equally depending of crystallinity and particle size. According to Fang et al. [3], temperature of maghemite formation is around $523 \mathrm{~K}$ (maximum DTA peak) and the formation of well-crystallized hematite from maghemite is obtained beyond $873 \mathrm{~K}$.

If we compare now, these experimental results with calculated values of standard reaction Gibbs functions $\Delta_{\mathrm{r}} \mathrm{G}_{\mathrm{T}}^{\circ}$ reported in table 2, three remarks could be formulated:

- $\Delta_{\mathrm{r}} \mathrm{G}_{\mathrm{T}}^{\circ}(2)<\Delta_{\mathrm{r}} \mathrm{G}_{\mathrm{T}}^{\circ}(1)$ : this is conform with the fact that lepidocrocite is less stable than goethite. That explains why lepidocrocite begins to decompose before goethite. On the other hand, its activation energy is lower than the goethite's one at equivalent crystallinity and particle sizes.

$-\Delta_{\mathrm{r}} \mathrm{G}_{\mathrm{T}}^{\circ}(3)<\Delta_{\mathrm{r}} \mathrm{G}_{\mathrm{T}}^{\circ}(2)$ : in contradiction with this result, hematite is never obtained directly from lepidocrocite. Maghemite always appears as an intermediate metastable phase.

- In addition, $\Delta_{\mathrm{r}} \mathrm{G}_{\mathrm{T}}^{\circ}$ (4) presents a very low value but nevertheless, hematite is obtained from maghemite at a relatively high temperature.

We can conclude that kinetic phenomena are more important than thermodynamics for explaining the experimental results found here. This conclusion allows to propose hypotheses of topotactic transformations. In fact, such transformations, in minimizing reaction energies, favor lower temperatures of decomposition. Obviously, topotactic transformations can only exist between solids displaying structural relationships. In these conditions, atom displacements are reduced, so that clear vectorial relations can be established between crystal 
parameters of the two structures. Therefore, one can consider that trivalent iron oxyhydroxides and oxides, belong to different structural types: goethite/hematite type and lepidocrocite/maghemite type.

\section{Hypothesis of topotactic thermal dehydration of goethite}

Goethite, $\alpha-\mathrm{FeO}(\mathrm{OH})$ exhibits an orthorhombic symmetry, space group Pnma $\left(\mathrm{N}^{\circ}\right.$ 62) [12]. Crystal parameters are: $\mathrm{a}=9.95 \AA, \mathrm{b}=3.01 \AA, \mathrm{c}=4.62 \AA$. The structure could be described as a three-dimensional structure built up with $\mathrm{FeO}_{3}(\mathrm{OH})_{3}$ octahedra which form large tunnels, spreading out along the direction [010] and where hydrogen atoms are located. Each octahedron is linked to eight neighboring octahedra by four edges and three vertices (fig.6). Oxygen atoms are in tetrahedral surroundings, either $\mathrm{OFe}_{3} \mathrm{H}$ or $\mathrm{OFe}_{3} \mathrm{H}$ (bond) ( see fig.1).

The structure of hematite, $\alpha-\mathrm{Fe}_{2} \mathrm{O}_{3}$, has been determined by Pauling and Hendricks in 1925 [13] and revisited in 1970 by Blake et al.[14]. It is isostructural with corundum, $\alpha-\mathrm{Al}_{2} \mathrm{O}_{3}$. The space group is $\mathrm{R} \overline{\mathrm{3}} \mathrm{c}$ ( $\mathrm{N}^{\circ} 167$, rhombohedral symmetry) and the lattice parameters given in the hexagonal cell are: $\mathrm{a}=5.0346 \AA, \mathrm{c}=13.752 \AA$. The structure has also a three-dimensional framework built up with trigonally distorted octahedra $\mathrm{FeO}_{6}$, linked to thirteen neighbors by one face, three edges and six vertices (fig.6). The surrounding of oxygen is tetrahedral $\mathrm{OFe}_{4}$ (fig.2. ).

The two structures, goethite and hematite can be described as a slightly distorted h.c.p.(hexagonally close-packed) stacking of anions $\left(\mathrm{O}^{2-}\right.$ or $\left.\mathrm{OH}^{-}\right)$(see fig.9a,b). Iron ions are located in octahedral sites, half the sites being occupied in goethite and two thirds of the sites in hematite [1]. In goethite, layers of anions are stacked perpendicularly to the c axis which value corresponds to the $\mathrm{ABA}$ stacking. On the other hand, in hematite, layers are also stacked along the $\mathrm{c}$ axis but periodic small shifts of anions and especially more important 
shifts of cations are responsible of the increase of the axis, three times ABA distance (see fig. 2 ). Similarity between the two structures appears beyond all doubt, on the figures 3 a and $3 \mathrm{~b}$, obtained by projection along the $\mathrm{c}$ axis. The loss of water in goethite doesn't modify extremely, anion layers. The main modification is due to displacements of iron cations in the inter-layer space in order to fill in tunnels found in goethite. Relationships between cell parameters are drawn on the figure 3 and vectorial relations are reported in table 3 . These results agree well with results mentioned by Cornell et al. [1] despite the fact these authors have chosen the unconventional space group Pbnm instead of Pnma [15] and have proposed relationships between directions rather than between cell parameters.

\section{Hypothesis of topotactic thermal dehydration of lepidocrocite}

Lepidocrocite, $\gamma-\mathrm{FeO}(\mathrm{OH})$, has an orthorhombic symmetry, space group $\mathrm{Cmcm}$ ( $\mathrm{N}^{\circ} 63$ ) [10, 16]. Cell parameters are: $\mathrm{a}=3.072 \AA, \mathrm{b}=12.516 \AA, \mathrm{c}=3.873 \AA$. The structure is built with $\mathrm{FeO}_{4}(\mathrm{OH})_{2}$ octahedra, giving rise to corrugated layers and therefore to a two-dimensional structure which is similar to the structure of copper hydroxide $\mathrm{Cu}(\mathrm{OH})_{2}$ [17]. Each octahedron is linked to eight neighboring octahedra by six edges and two vertices (fig.6). Oxygen atoms have two different surroundings, one is tetrahedral $\mathrm{OFe}_{4}$ while the second presents a peculiar feature insofar as it is constituted of only two iron and one hydrogen atoms: $\mathrm{OFe}_{2} \mathrm{H} \mathrm{[10]}$. Layers, parallel to $(\mathrm{a}, \mathrm{c})$ plane, are perpendicular to $\mathrm{b}$ axis and are linked together solely by a network of hydrogen bonds (see fig.4). The structure has been described in previous works [1, 15], as cubic close-packed (ccp) arrays of anions $\mathrm{O}^{2-}, \mathrm{OH}^{-}$, stacked according to $\mathrm{ABCA}$; iron atoms being placed in half the octahedral sites. That is wrong because each layer of oxygen atoms doesn't correspond to a close-packed array (see Fig. 5a and 9c) and periodicity of arrays is obtained for two stacks: $A B C A^{\prime} B^{\prime} C^{\prime} A$. This is due to the fact that in the structure of lepidocrocite, neighboring layers of $\mathrm{FeO}_{4}(\mathrm{OH})_{2}$ octahedra are shifted of a/2 along a axis ( 
Fig. 5b). This feature is also in relation with the high value of the $b$ parameter $(12.516 \AA)$ which corresponds to two inter-layer spaces (see fig.4). Anion sheets $A B C A^{\prime} B^{\prime} C^{\prime}$ are parallel to planes $\left(\begin{array}{lll}0 & 4 & 1\end{array}\right)$ and are stacked along a direction parallel to the row $\left[\begin{array}{lll}0 & 1 & 2\end{array}\right]$, as it can be seen on the figure $5 b$.

The structure of maghemite, $\gamma-\mathrm{Fe}_{2} \mathrm{O}_{3}$, is closely related to that of magnetite $\mathrm{Fe}_{3} \mathrm{O}_{4}$ [18], inverse spinel with a cubic structure, space group $\mathrm{Fd} \overline{3} \mathrm{~m}$, revisited by Okudera in 1996 [19]. In this case, oxygen anions give rise to a cubic close-packed structure (c.c.p.) with arrays

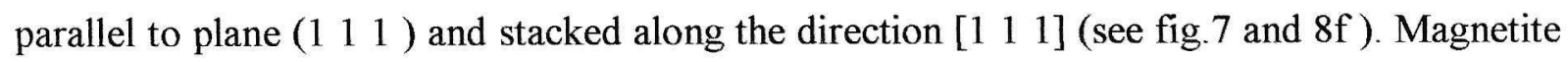
presents a mixed-valence $\mathrm{Fe}^{2+}, \mathrm{Fe}^{3+}$ ions, shared between octahedral and tetrahedral sites according to the formula: $\mathrm{Fe}^{3+}$ (tetra) $\left[\mathrm{Fe}^{3+} \mathrm{Fe}^{2+}\right.$ (octa) $] \mathrm{O}_{4}$. Maghemite, $\gamma-\mathrm{Fe}_{2} \mathrm{O}_{3}$ can be considered as an oxidized magnetite [20]. In spite of the oxidation of $\mathrm{Fe}^{2+}$, the cubic structure is practically preserved but the ejection of $11.1 \%$ of the iron, creates vacancies which appear rather in the octahedral sites [21]. The formula of maghemite could be formulated in relation with that of magnetite, as follows: $\mathrm{Fe}^{3+}$ (tetra) $\left[\mathrm{Fe}^{3+}{ }_{(5 / 3)} \square(1 / 3)(\right.$ octa $\left.)\right] \mathrm{O}_{4}$.

The crystal structure of maghemite has been described in the same cubic space group $\mathrm{Fd} \overline{3} \mathrm{~m}$ ( $\mathrm{a}=8.35 \AA)$ as that of magnetite [1]. Nevertheless vacancy ordering creates a superstructure which reduces the symmetry from cubic to tetragonal with $\mathrm{c} / \mathrm{a}=3$. The space group of the tetragonal form has been a matter of controversy. In the most recent publication on that topic [21], space group $\mathrm{P}_{1} 2_{1} 2$ was proposed from a determination by multiprofile Rietveld refinement. However, given the similarity of the two structures, maghemite can be studied and described in the cubic space group of magnetite. The structure is built with octahedra $\mathrm{FeO}_{6}$ and tetrahedra $\mathrm{FeO}_{4}$. Each octahedron is linked to six different octahedra via six edges and to six different tetrahedra via six vertices (Fig.6). As for tetrahedral surroundings, each tetrahedron is linked to twelve octahedra via its four vertices. The surrounding of oxygen is composed of four iron atoms; three in octahedral and one in tetrahedral, sites. The structure is 
drawn on the figure $7 \mathrm{a}$ in a perspective view, while in the figure $7 \mathrm{~b}$ is reported a projection of the structure along the direction [101], with an example of vacancy existing in the structure of maghemite. The hypothesis of a topotactic process giving rise to maghemite from lepidocrocite is described on the figure 8 . After the loss of water (fig. $8 \mathrm{~b}$ and $8 \mathrm{c}$ ), the structure of lepidocrocite collapses along the [010] direction (fig.8d). Given the shift of iron octahedra layers in lepidocrocite, of a/2 along the a parameter, these layers get finely overlapped after collapsing. Then, $3 / 8$ of the iron atoms migrate into tetrahedral sites ( the value of atom displacement is around $1.8 \AA$ ) and the structure of maghemite is obtained (fig. $8 \mathrm{e}$ and $8 \mathrm{f}$ ). Relationships between parameters of lepidocrocite and maghemite corresponding to the topotactic transformation proposed, are reported in table 4 . The main feature of this structural transformation is the big contraction of the crystal parameter along the [010] direction which is due to the loss of water followed by layers collapsing.

\section{Conclusion}

Obvious relationships exist between crystal structures of goethite and hematite and between crystal structures of lepidocrocite and maghemite. This fact explains the behavior of iron oxyhydroxides during the dehydration process carried out at relatively low temperatures. In these conditions, kinetic constraints surpass the second law of thermodynamic and allow the obtaining of metastable phases instead of stable phases. That is often the feature of topotactic transformations. All these iron oxy-hydroxides or oxides present a close-packed or a pseudo close-packed stacking of anions $\mathrm{OH}^{-}, \mathrm{O}^{2-}$, either hcp or ccp, apart from lepidocrocite, although it was considered, wrongly, as close-packed in previous work.

More particularly, that study has shown that the transformation of goethite into hematite is performed without great structural modifications. The hexagonally close-packed ( hcp ) arrays of anions found in goethite is practically conserved after the transformation ( slight shifts of oxygen atoms can be observed ). As for the dehydration of lepidocrocite into maghemite it is 
not the same case. We propose a new hypothesis of a topotactic transformation. Lepidocrocite doesn't present a cubic close-packed (ccp) stacking in contrast with results published in previous works. Nevertheless, after the loss of water, sheets of iron octahedra collapse to give rise to maghemite which presents, this time, ccp arrays of oxygen anions.

On the other hand, the study of the evolution of iron surroundings during the dehydration process of hydroxides is rather surprising. Condensation of iron octahedra after the loss of water is performed mainly by vertices instead of edges which number decreases. Hematite is the only phase which presents a face shared between two octahedra ( see fig.6 ). Moreover, it seems that octahedra linked by vertices give rise to structures more compact as it can be seen in table 5 .

\section{REFERENCES}

[1] Cornell R.M., Schwertmann U., The iron oxides, VCH Weinheim (1996).

[2] Gonzalez G., Sagarzazu A., Villalba R., Mater. Res. Bull., 35 (2000) 2295-2308.

[3] Fang J., . Kumbar A, Zhou W.L., Stokes K.L, Mater. Res. Bull., 38 (2003) 461-467.

[4] Kawakami T., Nasu S., Tsutsui T., Sasaki T., Yamada T., Endo S., Takano M., Katamoto T., J. Phys. Soc. Jpn, 72(10) (2003) 2640-2645.

[5] Majzlan J., Lang B.E., Stevens R., Navrotsky A., Woodfield B.F., Boerio-Goates J., Amer. Mineralogist, 88 (2003) 846-854.

[6] Majzlan J., Grevel K.D., Navrotsky A., Amer. Mineralogist, 88 (2003) 855-859.

[7] Hofmann M., Campbell S.J., Kaczmarek W.A., Welzel S., J. Alloys compounds, 348 (2003) 278-284.

[8] Walter D., Buxbaum G., Laqua W., J. Thermal Analysis and Calorimetry, 63 (2001) 733748 
[9] Dinesen A.R., Pedersen C.T., Koch C.B., J. Thermal Analysis and Calorimetry, 64 (2001) $1303-1310$.

[10] Cudennec Y., Lecerf A., C.R. Chimie, 6 (2003) 437-444.

[11] Atkins P.W., Oxford University Press, (1985) 214.

[12] Szytula A., Burewicz A., Dimitrijevic Z., Krasnicki S., Rzany H., Todorovic J., Wanic A., Wolski W., Physica Status Solidi, 26 (1968) 429-434.

[13] Pauling L., Hendricks S.B., J. Amer. Chem. Soc., 47 (1925) 781-790.

[14] Blake R.L., Zoltai T., Hessevick R.E., Finger L.W., U.S. dept. of Interior, Bureau of Mines, (1970) 1-20.

[15] Manceau A., Nagy K.L., Spadini L., Ragnarsdottir K.V., J.Colloid and Interface Science, $228,(2000) 306-316$.

[16] Zhukhlistov A.P., Crystallogr. Reports, 46(5) (2001) 730-733.

[17] Cudennec Y., Lecerf A., C.R. Acad. Sci. Paris, Ser.Ilc, 4 (2001) 885-891.

[18] Fleet M.E., J. Solid State Chem., 62 (1986) 75-82

[19] Okudera H., Kihara K., Matsumoto T., Acta Cryst., B52 (1996) 450-457.

[20] Kawakami T., Nasu S., Tsutsui T., Sasaki T., Yamada T., Endo S., Takano M., Katamoto T., J.Phys.Soc.Japan, 72(10) (2003) 2640-2645.

[21] Somogyvari Z., Svab E., Meszaros G., Krezhov K., Nedkov I., Sajo I., Bourée F., Applied Physics, A74 (2002) s1077-s1079. 
Table 1. Thermodynamic data at $298 \mathrm{~K}$ and $1 \mathrm{bar}$

\begin{tabular}{|c|c|c|c|c|}
\hline Phases & $\Delta \mathrm{H}_{\mathrm{f}, 298}^{\circ}\left(\mathrm{kJ}^{\mathrm{mol}}{ }^{-1}\right)$ & $\mathrm{S}_{298}^{\circ}\left(\mathrm{J}_{\mathrm{K}}^{-1} \cdot \mathrm{mol}^{-1}\right)$ & $\Delta \mathrm{G}_{\mathrm{f}, 298}^{\circ}\left(\mathrm{kJ} \cdot \mathrm{mol}^{-1}\right)$ & References \\
\hline$\alpha$-FeOOH goethite & -559.5 & 59.7 & -489.8 & {$[6]$} \\
\hline$\gamma$-FeOOH lepidocrocite & -549.4 & 65.1 & -480.1 & {$[6]$} \\
\hline$\alpha-\mathrm{Fe}_{2} \mathrm{O}_{3}$ Hematite & -824.2 & 87.4 & -742.2 & {$[11]$} \\
\hline$\gamma-\mathrm{Fe}_{2} \mathrm{O}_{3}$ Maghemite & -808.1 & 93.0 & -727.9 & {$[6]$} \\
\hline $\mathrm{H}_{2} \mathrm{O}$ liquid & -285.8 & 69.9 & -237.1 & {$[11]$} \\
\hline $\mathrm{H}_{2} \mathrm{O}$ gas & -241.8 & 188.8 & -228.6 & {$[11]$} \\
\hline
\end{tabular}

Table 2. Values of standard functions of reactions

\begin{tabular}{|c|c|c|c|}
\hline Reactions & $\Delta_{\mathrm{r}} \mathrm{H}_{298}^{\circ}\left(\mathrm{kJ} . \mathrm{mol}^{-1}\right)$ & $\Delta_{\mathrm{r}} \mathrm{S}_{298}^{\circ}\left(\mathrm{J} \cdot \mathrm{K}^{-1} \cdot \mathrm{mol}^{-1}\right)$ & $\Delta_{\mathrm{r}} \mathrm{G}_{\mathrm{T}}^{\circ}\left(\mathrm{kJ} \cdot \mathrm{mol}^{-1}\right)$ \\
\hline (1) $\begin{array}{c}\left(\mathrm{H}_{2} \mathrm{O} \text { liq }\right) \\
\left(\mathrm{H}_{2} \mathrm{O} \text { gas }\right)\end{array}$ & $\begin{array}{c}4.5 \\
26.5\end{array}$ & $\begin{array}{l}18.95 \\
78.4\end{array}$ & $\begin{array}{l}\Delta_{\mathrm{r}} \mathrm{G}_{298}^{\circ}=-1.15 \\
\Delta_{\mathrm{r}} \mathrm{G}_{373}^{\circ}=-2.7\end{array}$ \\
\hline $\begin{array}{l}\left(\mathrm{H}_{2} \mathrm{O} \text { liq }\right) \\
\left(\mathrm{H}_{2} \mathrm{O} \text { gas }\right)\end{array}$ & $\begin{array}{r}2.45 \\
24.45\end{array}$ & $\begin{array}{l}16.35 \\
75.8\end{array}$ & $\begin{array}{l}\Delta_{\mathrm{r}} \mathrm{G}_{298}^{\circ}=-2.42 \\
\Delta_{\mathrm{r}} \mathrm{G}_{373}^{\circ}=-3.8\end{array}$ \\
\hline $\begin{array}{l}\left(\mathrm{H}_{2} \mathrm{O} \text { liq }\right) \\
\left(\mathrm{H}_{2} \mathrm{O} \text { gas }\right)\end{array}$ & $\begin{array}{l}-5.6 \\
16.4\end{array}$ & $\begin{array}{l}13.55 \\
73.0\end{array}$ & $\begin{array}{l}\Delta_{\mathrm{r}} \mathrm{G}_{298}^{\circ}=-9.6 \\
\Delta_{\mathrm{r}} \mathrm{G}_{373}^{\circ}=-10.8\end{array}$ \\
\hline (4) & -16.1 & -5.6 & $\Delta_{\mathrm{r}} \mathrm{G}_{298}^{\circ}=-14.4$ \\
\hline
\end{tabular}


Table 3 : Vectorial relations between axes

Goethite $\rightarrow$ Hematite

\begin{tabular}{|c|c|c|c|}
\hline $\begin{array}{l}\alpha-\mathrm{FeO}(\mathrm{OH}) \\
\text { Pnma Goethite }\end{array}$ & $\underset{\text { Hematite }}{\alpha-\mathrm{Fe}_{2} \mathrm{O}_{3} \quad \mathrm{R} \overline{3} \mathrm{c}}$ & Relations between axes & Comments \\
\hline $\mathrm{a}_{\mathrm{G}}=9.95 \AA$ & $\mathrm{a}_{\mathrm{H}}=5.0346 \AA$ & $\overrightarrow{\mathrm{a}_{\mathrm{G}}} \Leftrightarrow 2 \overrightarrow{\mathrm{a}}_{\mathrm{H}} \quad(10.0692 \AA)$ & See figure 3 \\
\hline $\mathrm{b}_{\mathrm{G}}=3.01 \AA$ & $\mathrm{b}_{\mathrm{H}}=5.0346 \AA$ & $\overrightarrow{\mathrm{b}_{\mathrm{G}}} \Leftrightarrow \frac{\overrightarrow{\mathrm{a}_{\mathrm{H}}}+2 \overrightarrow{\mathrm{b}_{\mathrm{H}}}}{3}(2.907 \AA)$ & See figure 3 \\
\hline$c_{G}=4.62 \AA$ & $\mathrm{c}_{\mathrm{H}}=13.752 \AA$ & $\overrightarrow{\mathrm{c}_{\mathrm{G}}} \Leftrightarrow \overrightarrow{\frac{\mathrm{c}_{\mathrm{H}}}{3}}$ & $\begin{array}{l}\text { See figure } 1 \\
\text { and figure } 2\end{array}$ \\
\hline I & $\gamma=120^{\circ}$ & & \\
\hline
\end{tabular}

Table 4 : Vectorial relations between axes

lepidocrocite $\rightarrow$ maghemite

\begin{tabular}{|c|c|c|c|}
\hline $\begin{array}{l}\gamma-\mathrm{FeO}(\mathrm{OH}) \\
\mathrm{Cmcm} \\
\text { Lepidocrocite }\end{array}$ & $\underset{\text { Maghemite }}{\gamma-\mathrm{Fe}_{2} \mathrm{O}_{3} \quad \mathrm{Fd} \overline{3} \mathrm{~m}}$ & Relations between axes & Comments \\
\hline $\mathrm{a}_{\mathrm{L}}=3.072 \AA$ & $\mathrm{a}_{\mathrm{M}}=8.35 \AA$ & $\overrightarrow{a_{L}} \Leftrightarrow \frac{\overrightarrow{a_{M}}-\overrightarrow{c_{M}}}{4}(2.95 \AA)$ & $\begin{array}{l}\text { distance between iron of } \\
\text { two neighboring } \\
\text { octahedra. }\end{array}$ \\
\hline $\mathrm{b}_{\mathrm{L}}=12.516 \AA$ & $\mathrm{b}_{\mathrm{M}}=8.35 \AA$ & $\overrightarrow{\mathrm{b}_{\mathrm{L}}} \Leftrightarrow \overrightarrow{\mathrm{b}_{\mathrm{M}}}$ & $\begin{array}{l}\text { big contraction due to } \\
\text { the loss of water. }\end{array}$ \\
\hline $\mathrm{c}_{\mathrm{L}}=3.873 \AA$ & $\mathrm{c}_{\mathrm{M}}=8.35 \AA$ & $\overrightarrow{c_{L}} \Leftrightarrow \frac{\overrightarrow{a_{M}}+\overrightarrow{c_{M}}}{4}(2.95 \AA)$ & $\begin{array}{l}\text { weak contraction of } \\
\text { corrugated octahedra } \\
\text { chains of lepidocrocite. }\end{array}$ \\
\hline
\end{tabular}


Tableau 5: different surroundings of iron octahedron or tetrahedron

\begin{tabular}{|l|c|c|c|c|}
\hline \multicolumn{1}{|c|}{ Phases } & $\begin{array}{c}\text { Number of iron } \\
\text { atoms in contact } \\
\text { with one octahedron } \\
\text { or tetrahedron }\end{array}$ & $\begin{array}{c}\text { Number of faces } \\
\text { shared for one } \\
\text { octahedron or } \\
\text { tetrahedron }\end{array}$ & $\begin{array}{c}\text { Number of edges } \\
\text { shared for one } \\
\text { octahedron or } \\
\text { tetrahedron }\end{array}$ & $\begin{array}{c}\text { Number of vertices } \\
\text { shared for one } \\
\text { octahedron or } \\
\text { tetrahedron }\end{array}$ \\
\hline $\mathrm{Fe}(\mathrm{OH})_{2}$ & 6 & 0 & 6 & 0 \\
\hline$\gamma-\mathrm{FeO}(\mathrm{OH})$ & 8 & 0 & 6 & 2 \\
\hline$\alpha-\mathrm{FeO}(\mathrm{OH})$ & 8 & 0 & 4 & $3(2+1 \times 2)$ \\
\hline \multicolumn{1}{c}{ Octa } & 12 & 0 & 6 & 6 \\
$\gamma-\mathrm{Fe}_{2} \mathrm{O}_{3}$ & 12 & 0 & 0 & $6(3 \times 3)$ \\
\hline$\alpha-\mathrm{Fe}_{2} \mathrm{O}_{3}$ & 13 & 1 & 3 & 6 \\
\hline
\end{tabular}




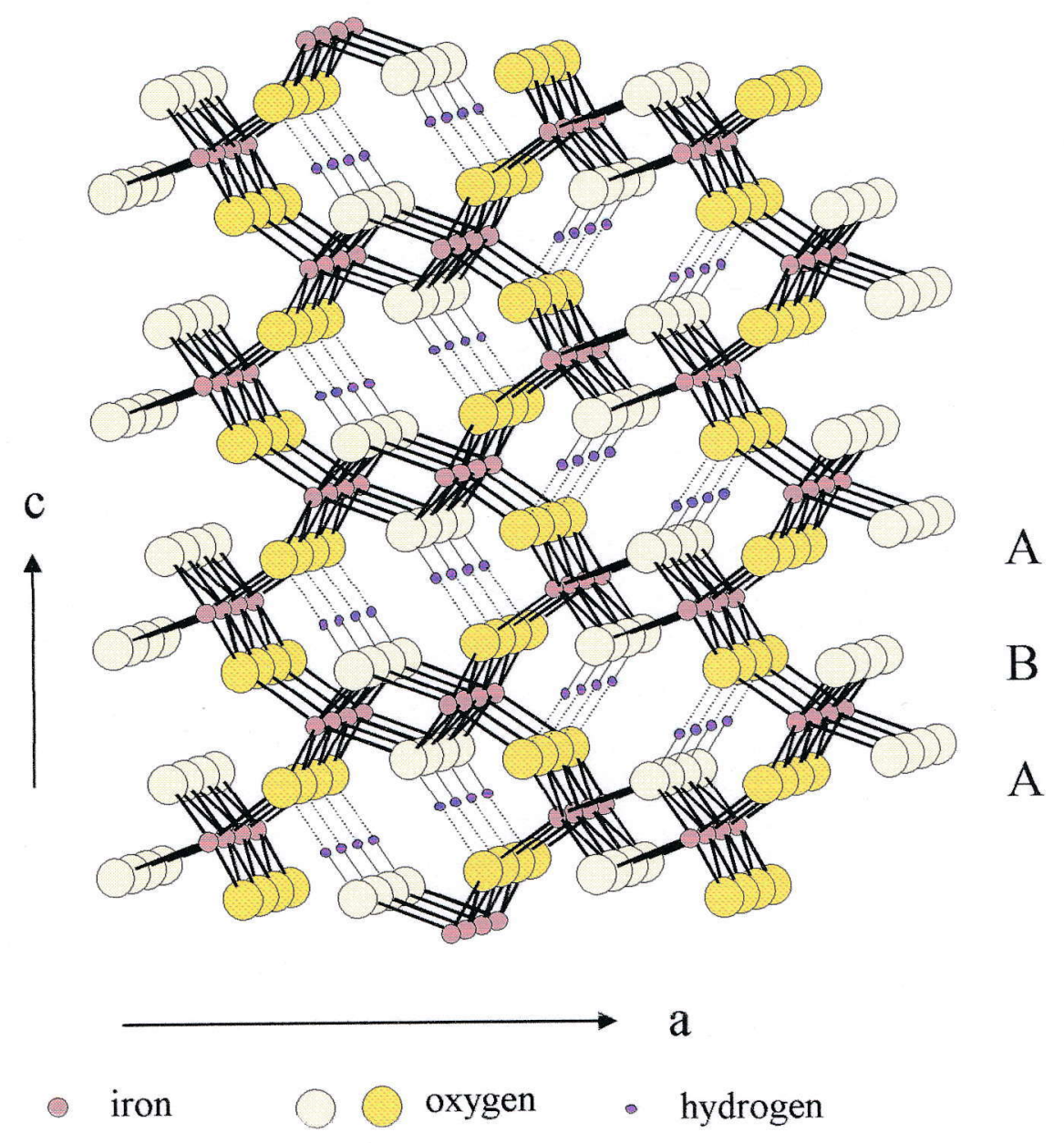

Fig. 1 : Crystal structure of goethite 


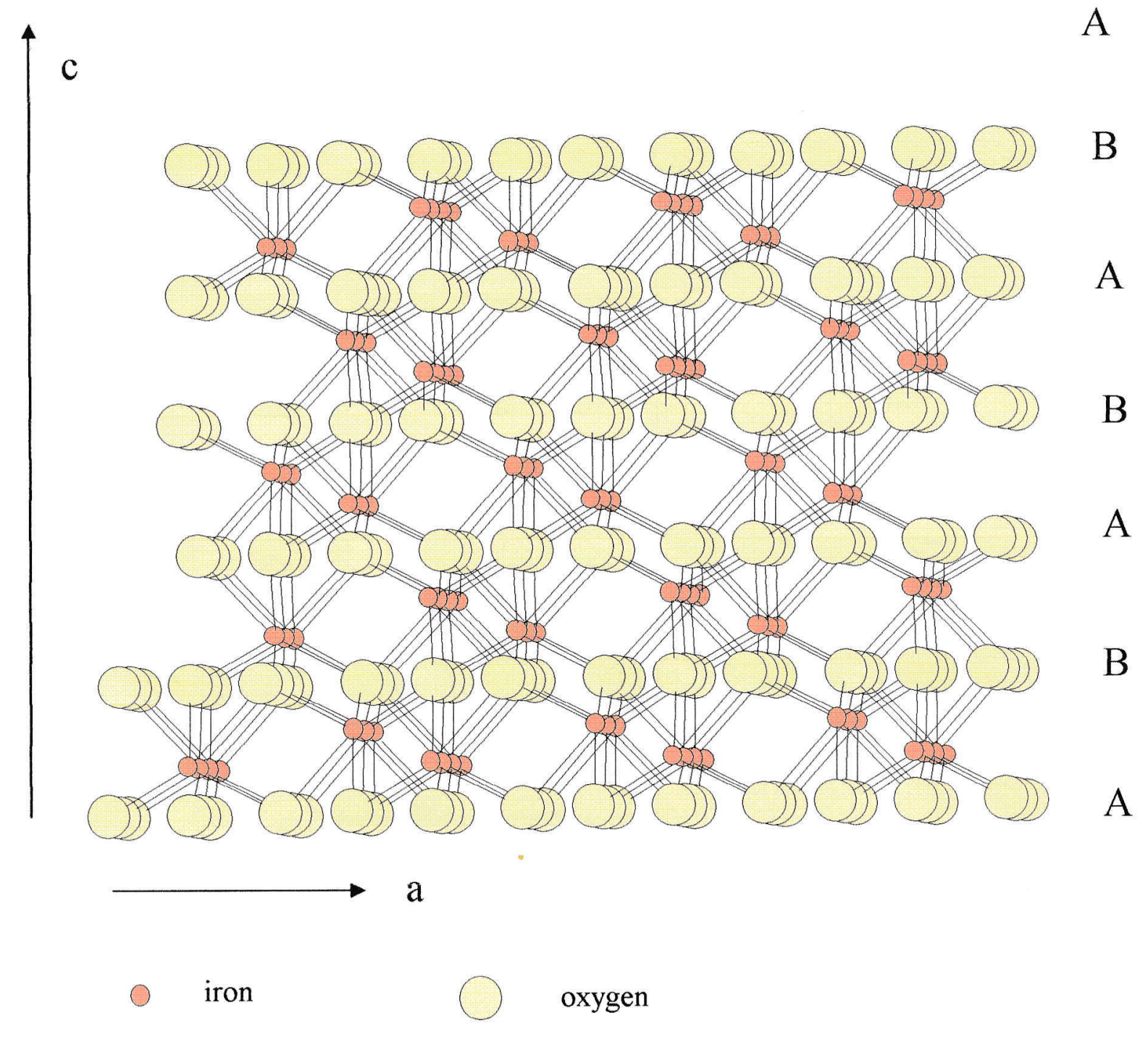

Fig. 2 : Crystal structure of hematite 
Figure 3: Comparaison of goethite and hematite

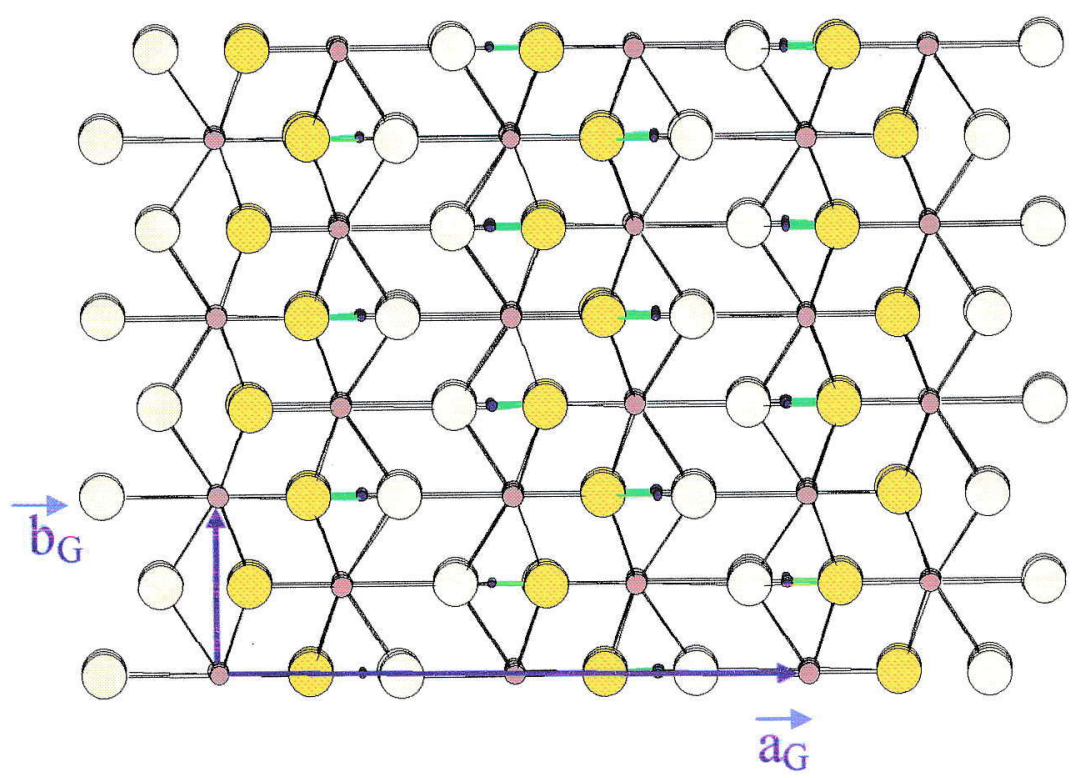

Figure $3 \mathrm{a}$ : Projection of goethite along $\mathrm{c}$ axis

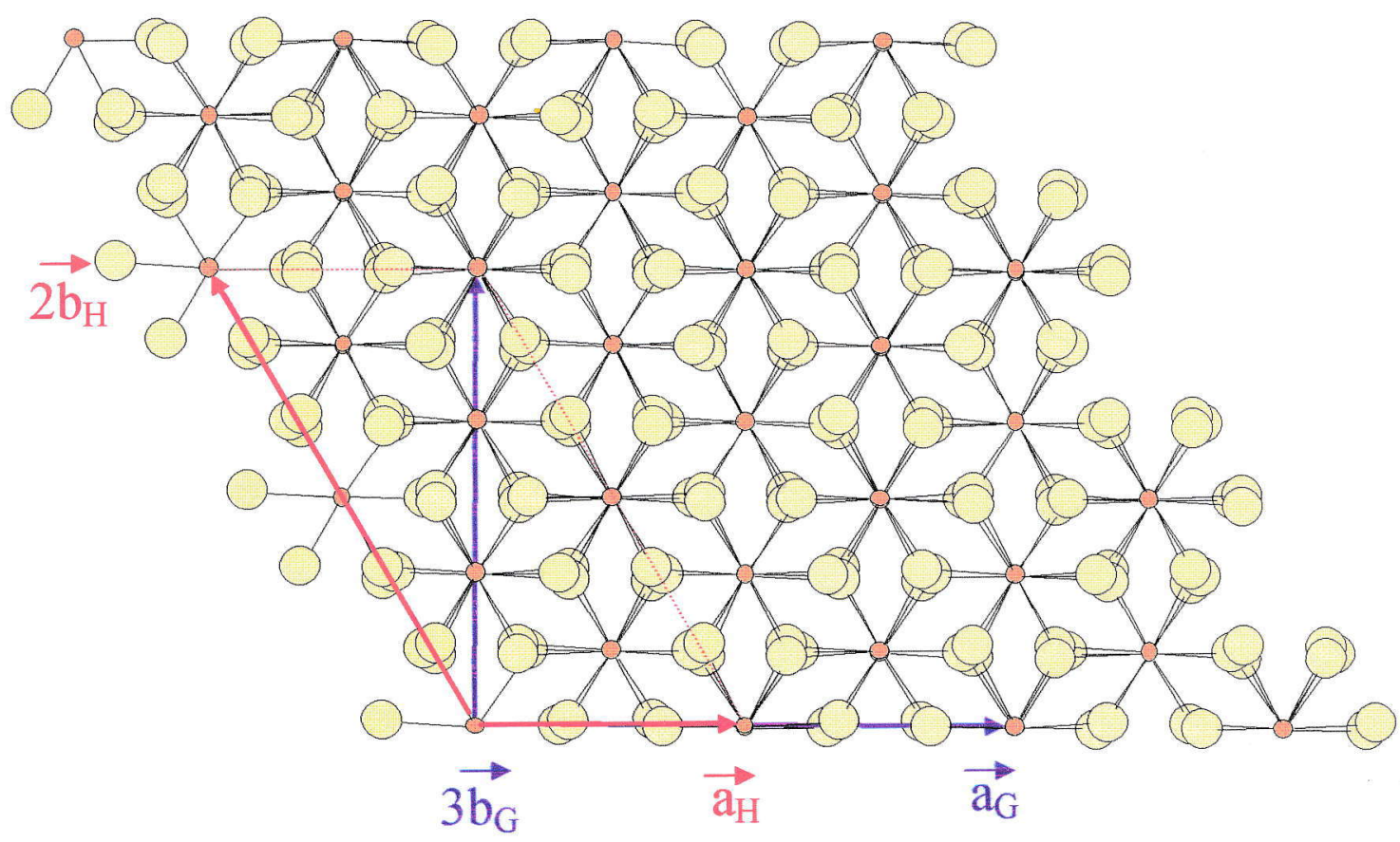

Figure 3b: Projection of hematite along $\mathrm{c}$ axis 


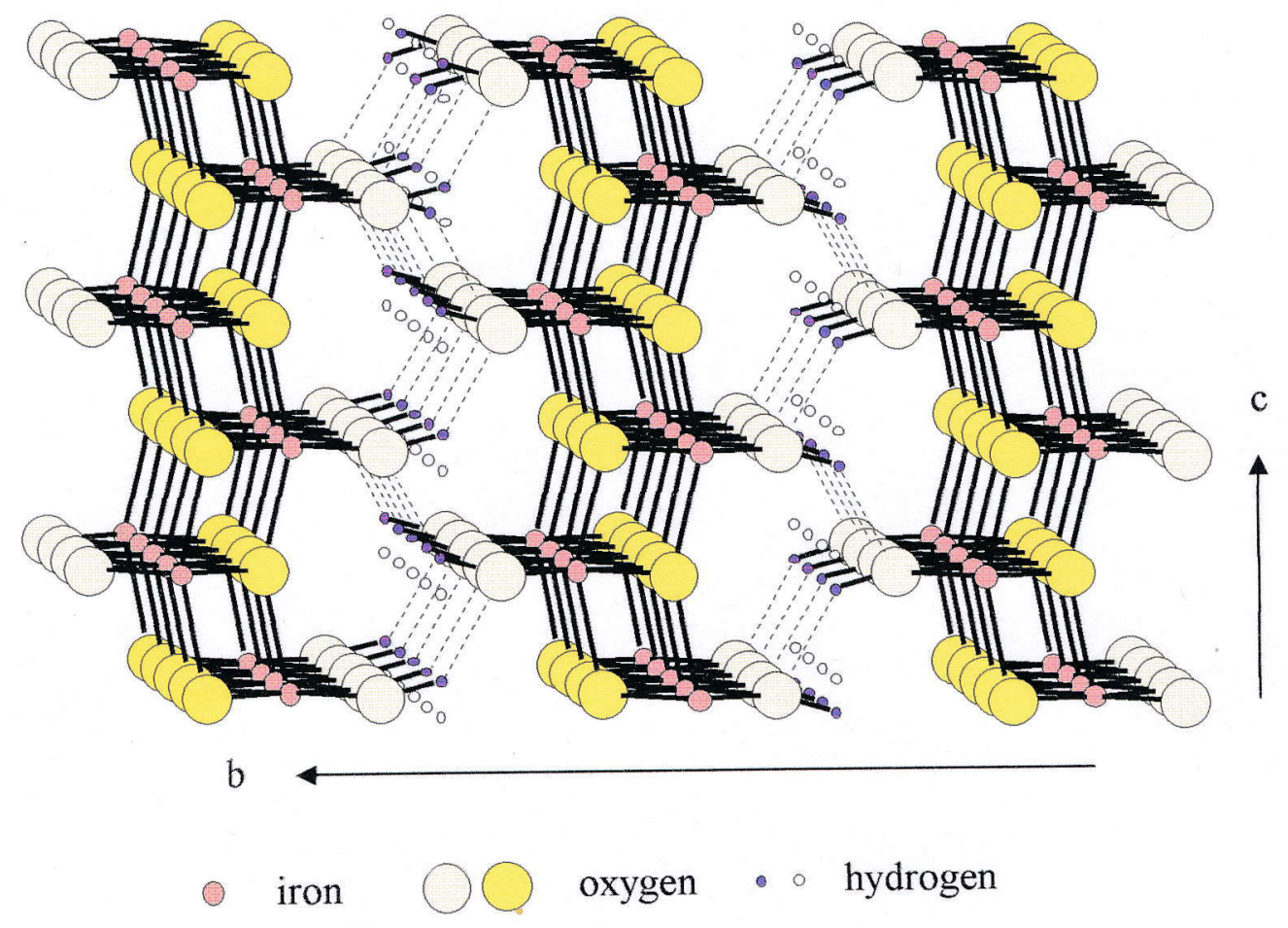

Figure 4: Crystal structure of lepidocrocite 
Figure 5: lepidocrocite, stacking of oxygen layers

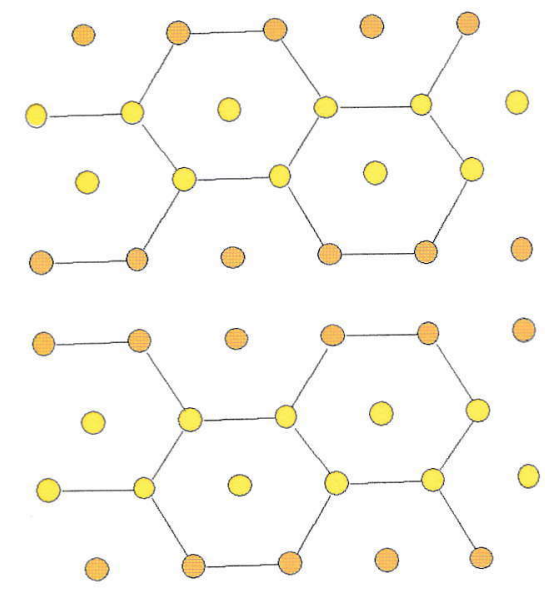

5a : arrays of oxygen atoms

// $\left(\begin{array}{lll}0 & 4 & 1\end{array}\right)$

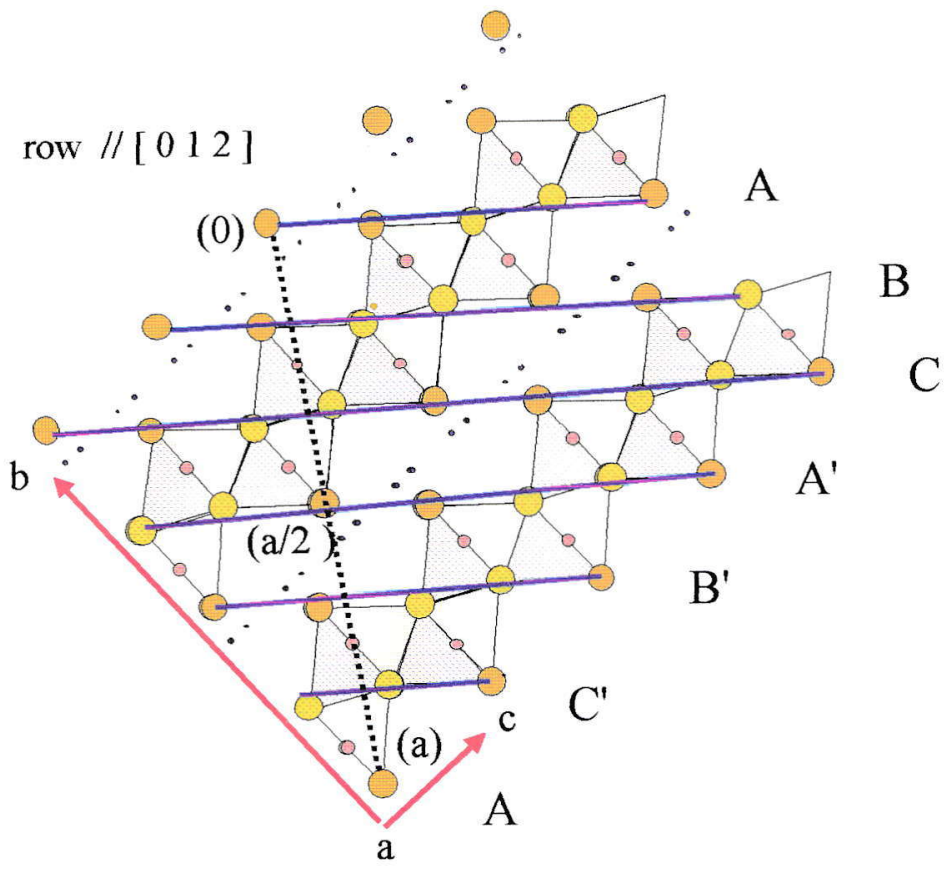

5b : projection of arrays // ( $\left.\begin{array}{lll}0 & 4 & 1\end{array}\right)$

along a 


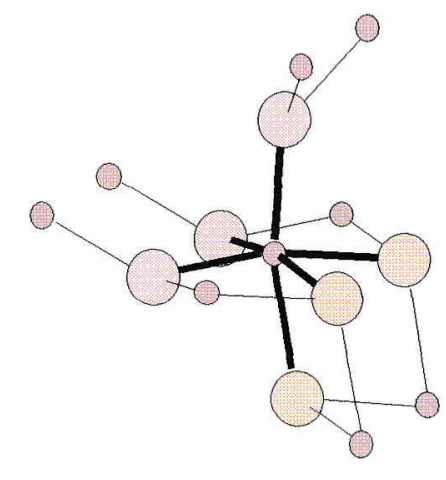

6a: Goethite

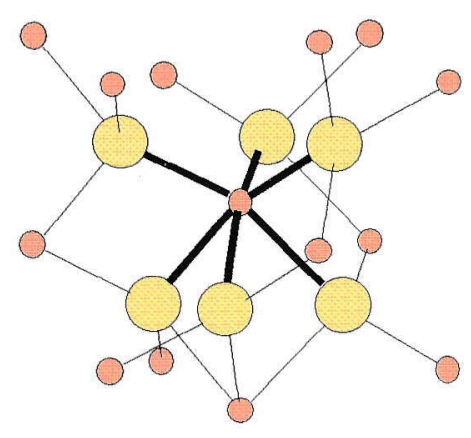

6b: Hematite

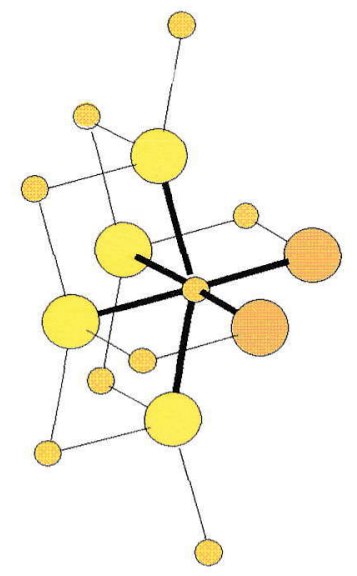

6c: Lepidocrocite

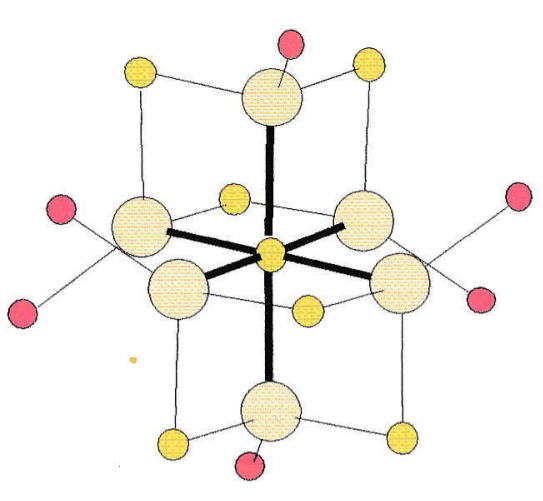

6d: Maghemite

Figure 6: Surroundings of iron 


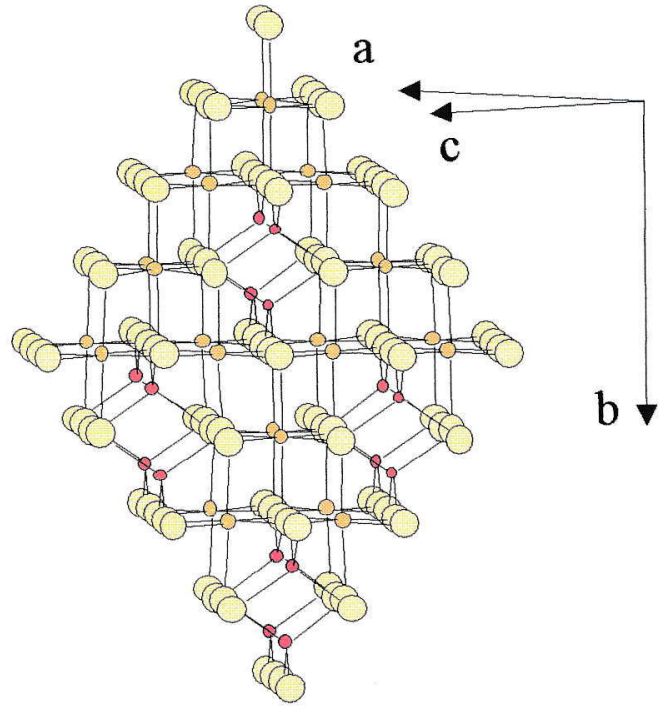

$7 \mathrm{a}$

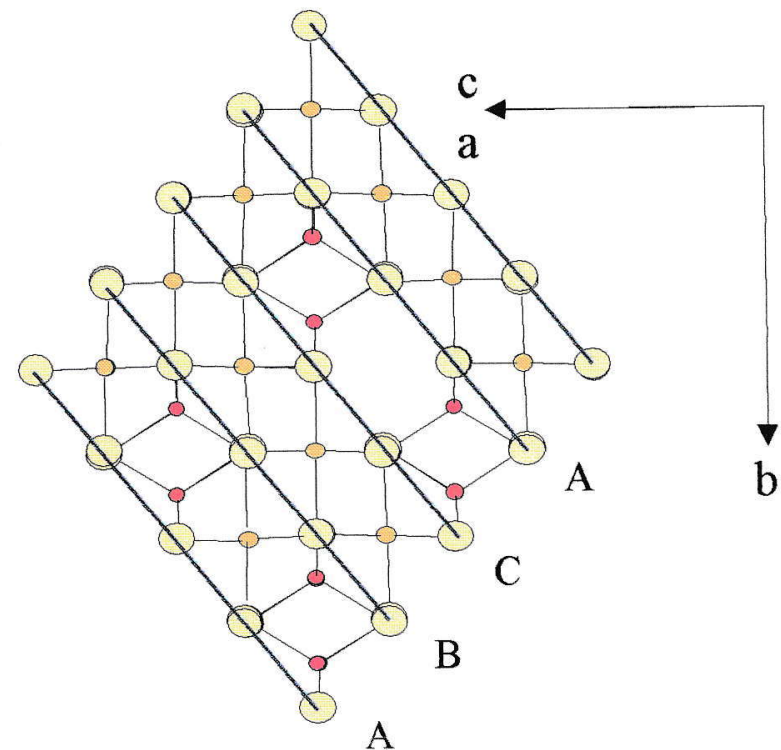

$7 b$

Figure 7: Structure of magnetite, maghemite ccp arrays // (111) stacked along [111]

Figure 8 : Topotactic transformation

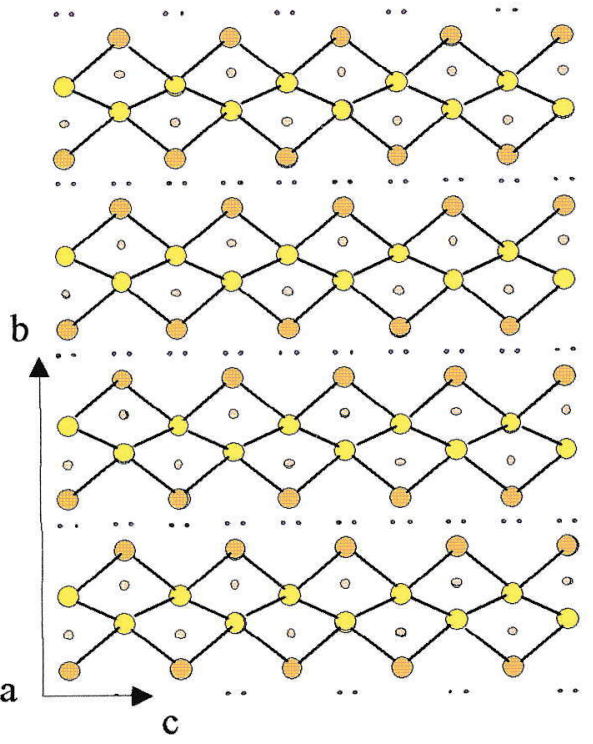

8a: Lepidocrocite

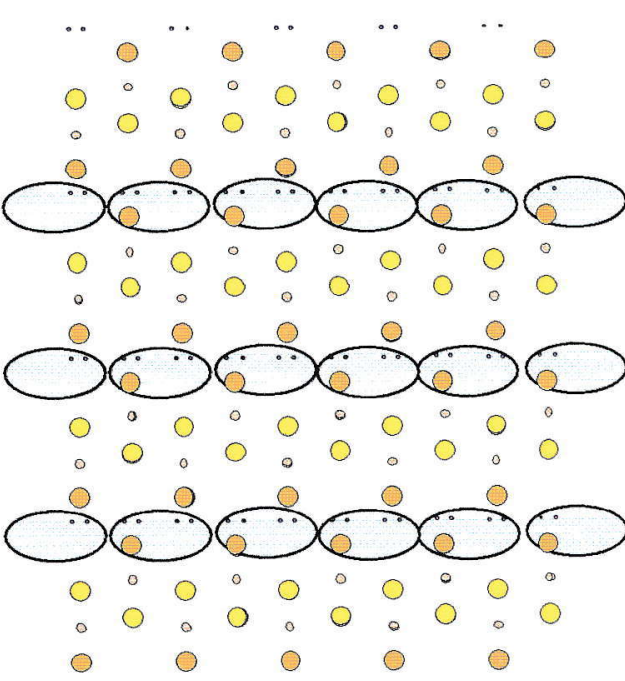

$8 \mathrm{~b}$ : Loss of water 


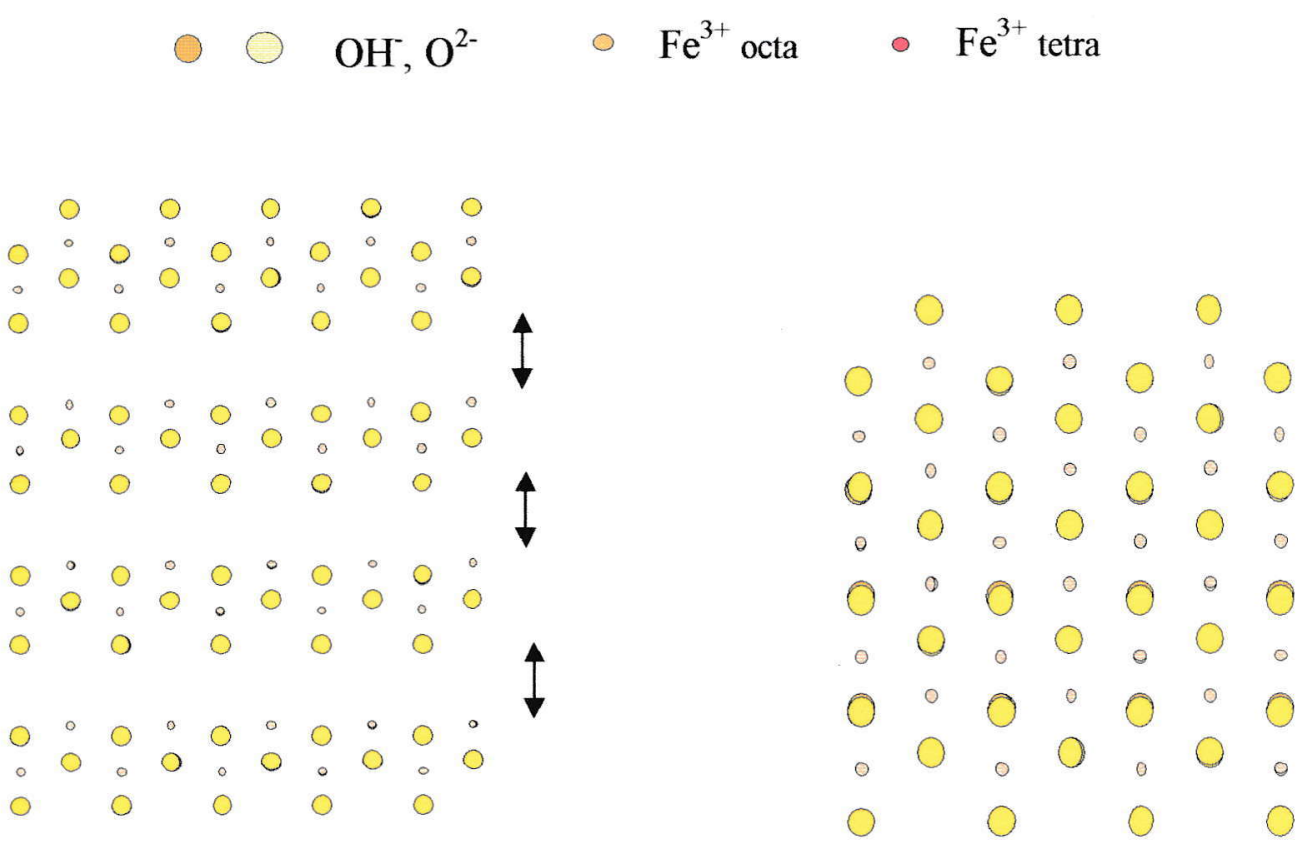

8c: contraction of the structure along $\mathrm{b}$

8d: Collapsed structure

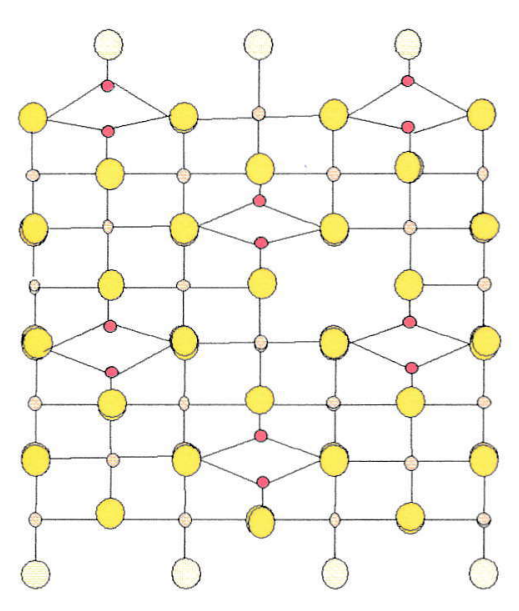

$8 \mathrm{e}: 3 / 8$ of iron ions move in tetrahedral sites

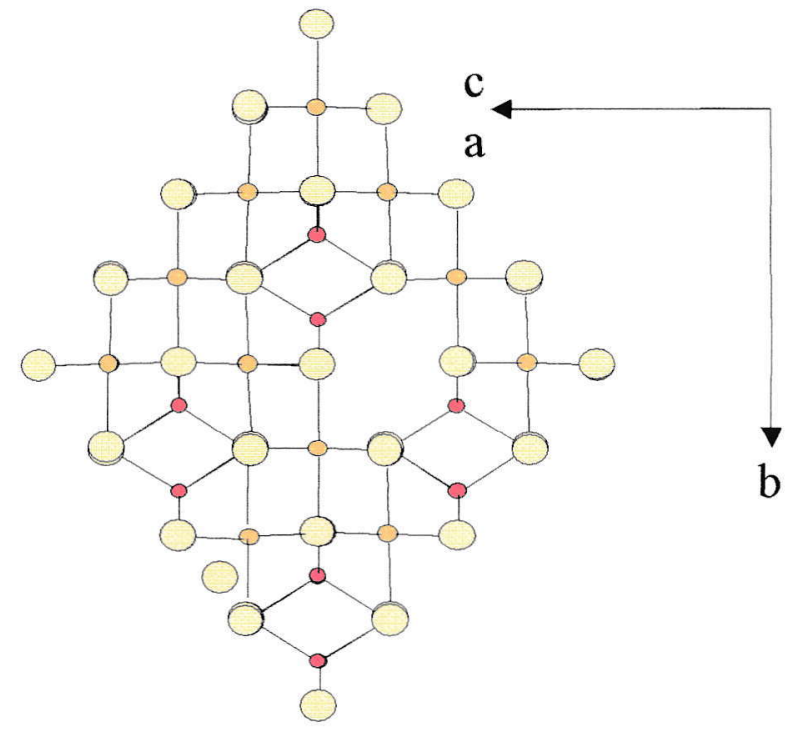

8f : Structure of maghemite

Figure 8 : Topotactic transformation Lepidocrocite Maghemite 


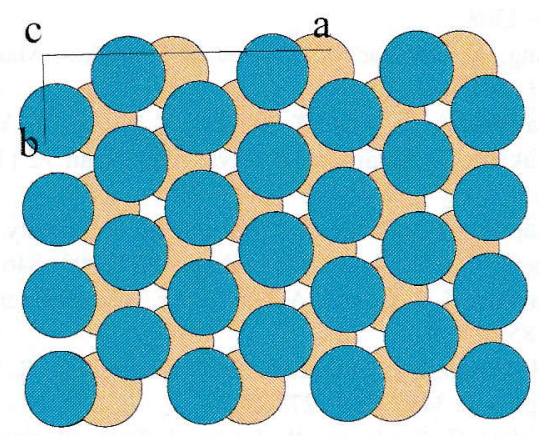

(a)

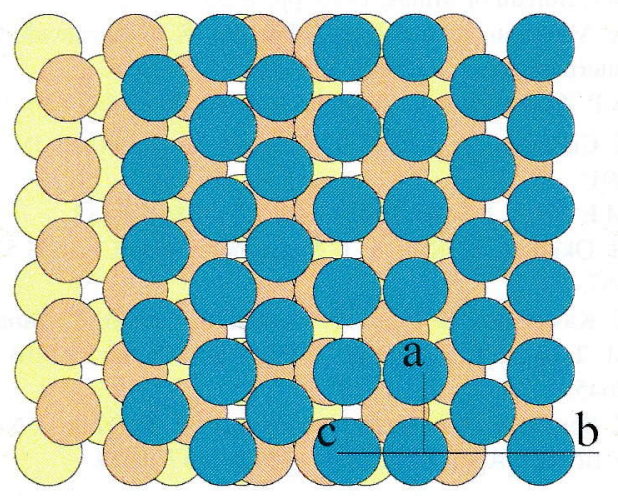

(c)

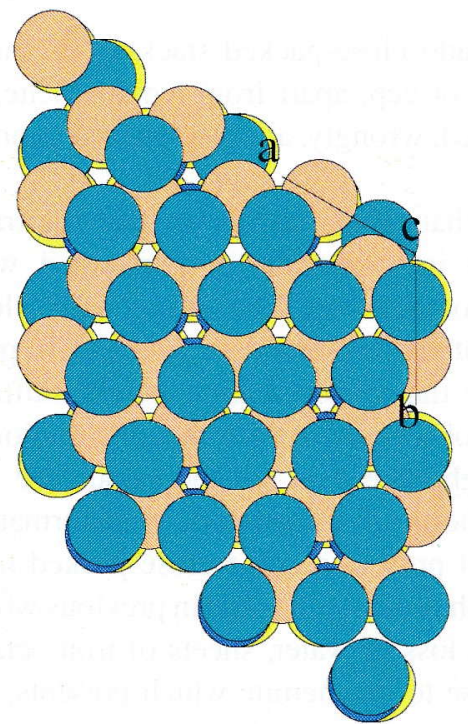

(b)

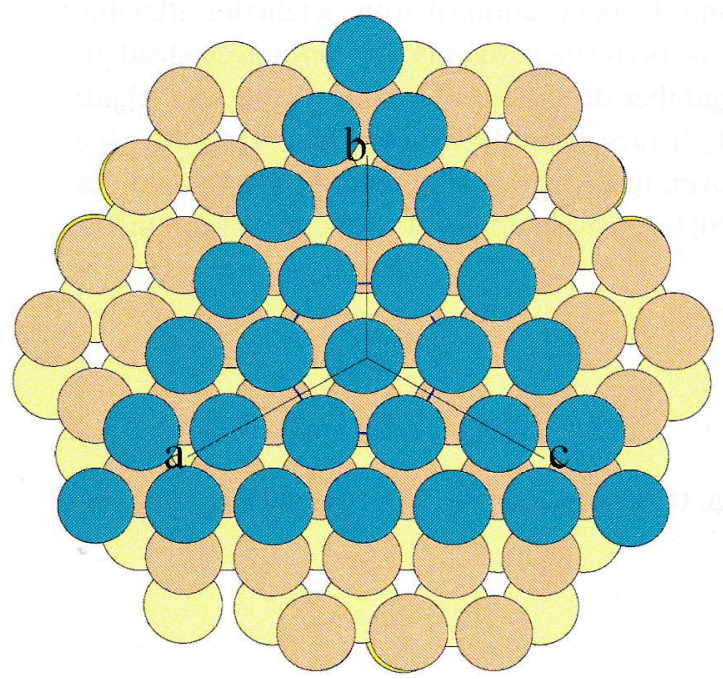

(d)

\section{A stacking

Fig. 9. Anion $\mathrm{O}^{2-}, \mathrm{OH}^{-}$stacking. (a) Goethite hcp A B; (b) Hematite hep A B; (c) Lepidocrocite; (d) Magnetite, maghemite ccp A B C. 